\title{
Observed and Perceived Climate Change and Variability and Small Holder Farmers' Vulnerability: The Case of Janamora District, Northwestern Ethiopia
}

\author{
Adamsew Marelign $^{1} \quad$ Solomon Addisu ${ }^{2} \quad$ Asnake Mekuriaw $^{2}$ \\ 1.Department of Natural Resources Management University of Gondar, Gondar Ethiopia \\ 2.Department of Natural Resources Management, College of Agriculture and Environmental Sciences, Bahir Dar \\ University, Bahir Dar, Ethiopia
}

\begin{abstract}
In the context of observed climate change and variability and their impact on livelihoods; This study intended to assess farmers' vulnerability to climate change and variability in Janamora district, northwestern Ethiopia. Primary data for the study was collected through questionnaire from 138 respondents selected through multi-stage sampling technique based on agro-ecology. Secondary data was collected from meteorological stations. Mann-Kendall and Chi-square tests were employed to test observed and perceived climate change and variability respectively. While LVI and LVI-IPCC methods were used to assess farmers' vulnerability to climate change and variability using SPSS version 23. The results revealed significant increasing trend in annual average temperature in all stations except Debark and insignificant trend in annual rainfall as well as a higher rainfall variability. Similarly, 69.6 and $80.4 \%$ of the interviewed farmers were aware of an increase in temperature and a decrease in rainfall respectively. Moreover, $\chi^{2}$ test showed that a significant variation (significant at $\mathrm{P}<0.05$ ) in perception to temperature and rainfall between agro-ecology. The overall vulnerability result in the case of LVI was $0.425,0.454$ and 0.471 for Dega, Woyna Dega and Kolla agro-ecological zones respectively. Similar result was found using the LVI-IPCC approach which was $0.035,0.041$ and 0.049 for Dega, Woyna Dega and Kolla agro-ecological zones respectively. Both LVI and LVI-IPCC results revealed that Kolla was the most vulnerable and Dega was the least vulnerable to climate change and variability. The study suggested improving the literacy level and integrating rural development schemes to increase adaptive capacity. Similarly, further studies should be conducted in the future.
\end{abstract}

Keywords: Perception, Vulnerability, Climate Change and Variability, Livelihood, Janamora

DOI: $10.7176 / \mathrm{JEES} / 9-8-04$

Publication date: August $31^{\text {st }} 2019$

\section{Introduction}

Climate change is the most significant environmental threat of the $21^{\text {st }}$ century (Edame et al., 2011). The world's climate is continuing to change at rates that are projected to be new in recent human history (ILRI, 2006). The IPCC (2001) report showed that, the global mean surface temperature has been increased by $0.6^{\circ} \mathrm{C}\left(0.4^{\circ} \mathrm{C}\right.$ to 0.8 ${ }^{\circ} \mathrm{C}$ ) over the last 100 years. This increasing global mean surface temperature is lead to changes in precipitation and atmospheric moisture (IPCC, 2001). Evidences indicated that the natural climatic variability in combination with climate change will adversely affect millions of livelihoods around the world (IPCC, 2007a). In Africa, mean temperature levels have increased whereas precipitation levels have declined (IPCC, 2001). Temperature increases between $3^{\circ} \mathrm{C}$ and $4^{\circ} \mathrm{C}$ in Africa by the end of the $21^{\text {st }}$ century (Bryan et al., 2010). Africa is the most vulnerable continent to climate change and climate variabilities (Challinor et al., 2007). Many African countries are vulnerable to climate change since their economies highly depend on climate sensitive agricultural production (Mahmud Yesuf et al., 2008). Like other sub-Saharan countries, in Ethiopia, there has been a warming trend increasing by about $0.37^{\circ} \mathrm{C}$ every ten years (NMA, 2007). Climate change presents Ethiopian farmers and pastoralists with a new set of challenges (MOARD, 2010). It is highly connected to poverty, loss of coping and adaptive capacity (Temesgen Deressa et al., 2008; Kaur et al., 2010; Temesgen Deressa, 2010).

Ethiopia is one of the most highly vulnerable to future climate change among African countries (Conway and Schipper, 2011). Agriculture, water and human health sectors are the most vulnerable to climate variability and change as well as in terms of livelihood approach smallholder rain-fed farmers and pastoralists are found to be the most vulnerable (NMA, 2007; Kaur et al., 2010). Ethiopia experienced 10 wet years and 11 dry years over the last 55 years, demonstrating the strong inter-annual variability (NMA, 2007). Mountain regions of Ethiopia are more susceptible to climate change impacts and vulnerabilities (Belay Simane et al., 2014). Particularly Janamora district is mountainous and often-rugged landscape dominated by the great Semien mountain block (specifically Chennek and Bwahit mountains) with prevailing and highly variable climate conditions.

Livelihood vulnerability index: composite index approach and IPCC framework approach The livelihood vulnerability index (LVI) composite index approach uses multiple indicators to measure 
vulnerability to natural disasters and climate variability, social and economic characteristics of households that affect their adaptive capacity, current health, food, and water resource characteristics that determine their sensitivity to climate change impacts (Hahn et al., 2009). A balanced weighted approach is utilized in computing the LVI. The livelihood vulnerability index IPCC approach (LVI-IPCC) was developed as an alternative method for calculating the LVI that incorporates the IPCC vulnerability definition (IPCC, 2007b). LVI-IPCC used to assess exposures, sensitivity and adaptive capacity that make the contributing factor of vulnerability to climate change and variability.

The LVI has been used in varied studies. For instance, Can et al. (2013) used this method to assess risks from flood incidence. Similarly, Shah et al. (2013), Koya et al. (2017) and Etwire et al. (2013) applied the livelihood vulnerability index for vulnerability assessment. Particularly in Ethiopia Solomon Addisu et al. (2016) used the livelihood vulnerability IPCC approach (LVI-IPCC) in assessing climate change impacts in lake Tana sub-basin. Similarly, Chala Dechassa et al. (2016) and Theodrose Sisay (2016) used this method to assess the vulnerability of farmers to climate variability and change. The LVI-IPCC conceptual framework diagram (Figure 1) illustrates how LVI sub-components (far right) relate to major components (second from right) that determine scores for LVI-I PCC contributing factors (second from left), which make up the overall LVI-IPCC vulnerability (left) for the study area. On the other hand, the difference between exposure and adaptive capacity multiplied by sensitivity gives vulnerability that means (exposure - adaptive capacity) *sensitivity equals to vulnerability (Figure 1).

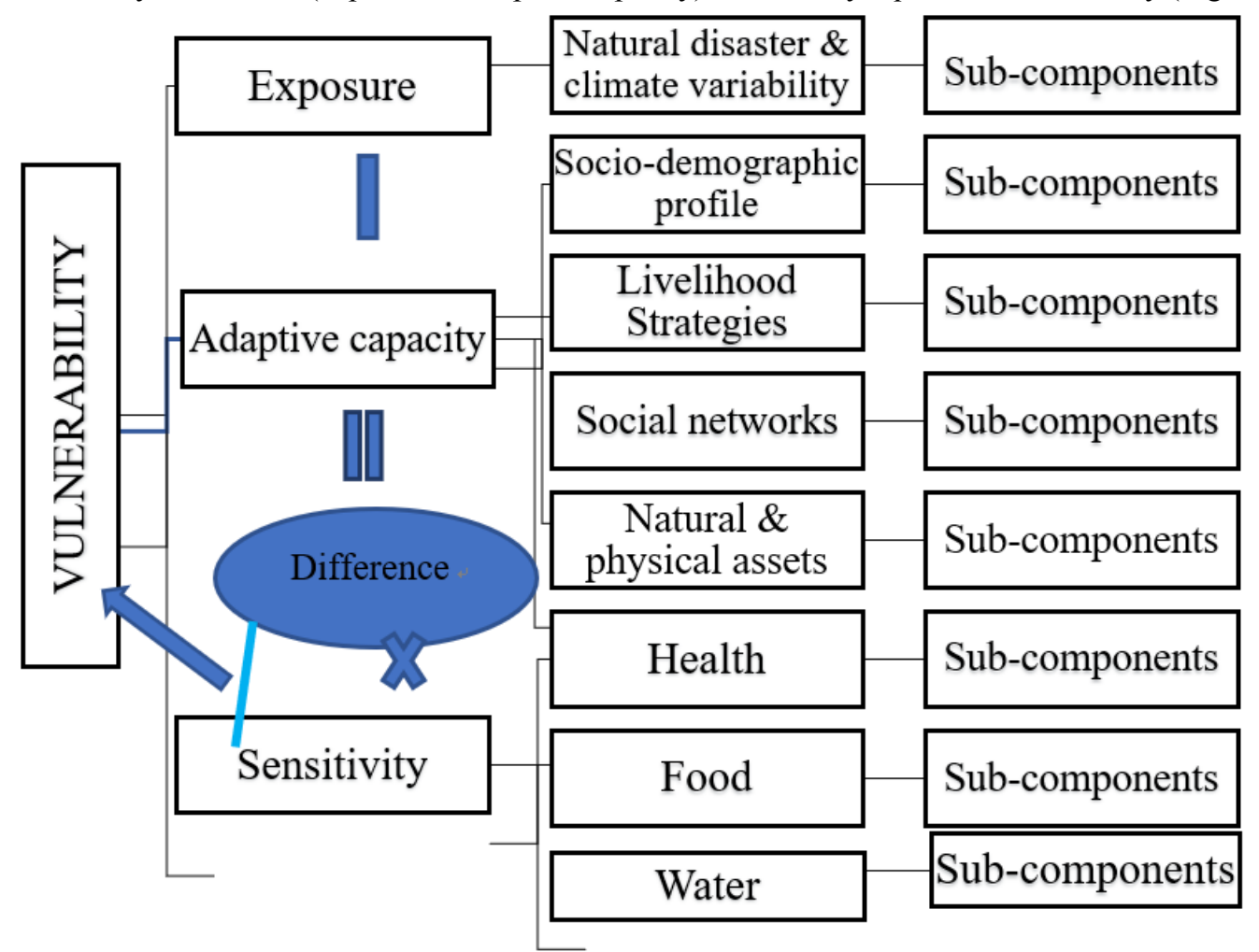

Figure 1: LVI and LVI-IPCC framework (Source: modified from Solomon Addisu et al., 2016).

Few studies assessed the impact of climate change in Ethiopia. For example, a research conducted in the regional states of Ethiopia by Temesgen Deressa et al. (2008) tried to assess Ethiopian farmer's vulnerability to climate change across regional states.

However, most of these studies are very general and the results are aggregated at national or State levels. Therefore, all may not reflect local contexts of Janamora district because site-specific issues require site-specific knowledge and experience (IPCC 2007a). Due to high projection of significant future climate change in Ethiopia in the coming decades (Belay Simane et al., 2014) aggregate national vulnerability result does not capture the complexity of vulnerability at agro-ecological level, so agricultural productivity remains challenged. This is particularly true for Janamora district with variable topographical region with variable climatic condition with the occurrence of droughts negatively affect the livelihoods. As a result, assessing the farmers' vulnerability to climate change and variability is very crucial. 


\section{Materials and Methods \\ Description of the study area}

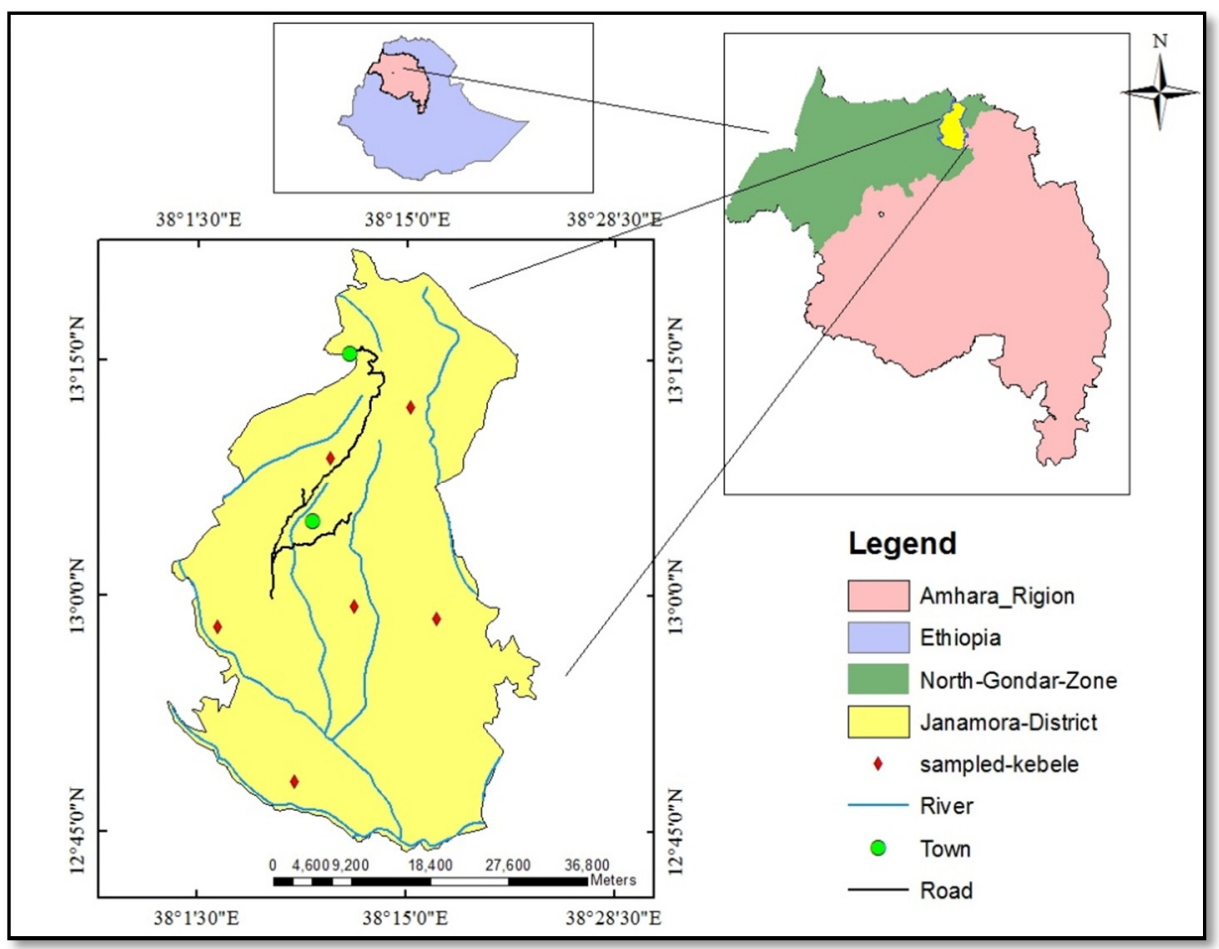

Figure 2 Location map of the study area

The study was conducted in Janamora District North Gondar Zone of Amhara National Regional State, Ethiopia. Geographically, it is located between $12^{\circ} 44^{\prime} 21.2^{\prime \prime} \mathrm{N}-13^{\circ} 21^{\prime} 19.3^{\prime \prime} \mathrm{N}$ and $38^{\circ} 0^{\prime} 0.3^{\prime \prime} \mathrm{E}-38^{\circ} 22^{\prime} 40.5^{\prime \prime}$ E (Figure 2). Elevation of the district ranges from 1238- $4512 \mathrm{~m}$ a.s.l. The district is part of the Simien mountains national park. About $104 \mathrm{Km}^{2}$ area of the park is under Janamora district and about 9 kebeles of the district is found in and around the park. The total annual precipitation of Janamora district is $984.3 \mathrm{~mm}$ from 2004 - 2016. The district is characterized by unimodal (one rainy season) type of rainfall. Monthly rainfall and monthly minimum, maximum and average temperature for the study area starting from year 2004 to 2016 is illustrated in Figure 3. Janamora district is characterized by steeply dissected and variable topography. It is found between 1238 - $4512 \mathrm{~m}$ a.s.1. Most area of the district is very steep slope ranges from $0-250 \%$ of gradient. Based on traditional agroecological zones of Ethiopia (Ministry of Agriculture, 2000), the district is classified in to three major agroecological zones of Dega (highland), Woyna Dega (midland) and Kolla (lowland). Kolla consists of 25\% of the district; Woyna Dega consists 27\%, and Dega consists of $49 \%$ of the district. The entire population of Janamora district is 208719 with 44408 households in 2017 . From this $49 \%$ were male and $51 \%$ were female. The socioeconomic characteristics includes agriculture, small scale trade, micro and small enterprise. However, above $90 \%$ of the people livelihood is mixed farming which is a subsistence form of agricultural production. Some of the population also depends on aid from Productive safety net program (PSNP). 


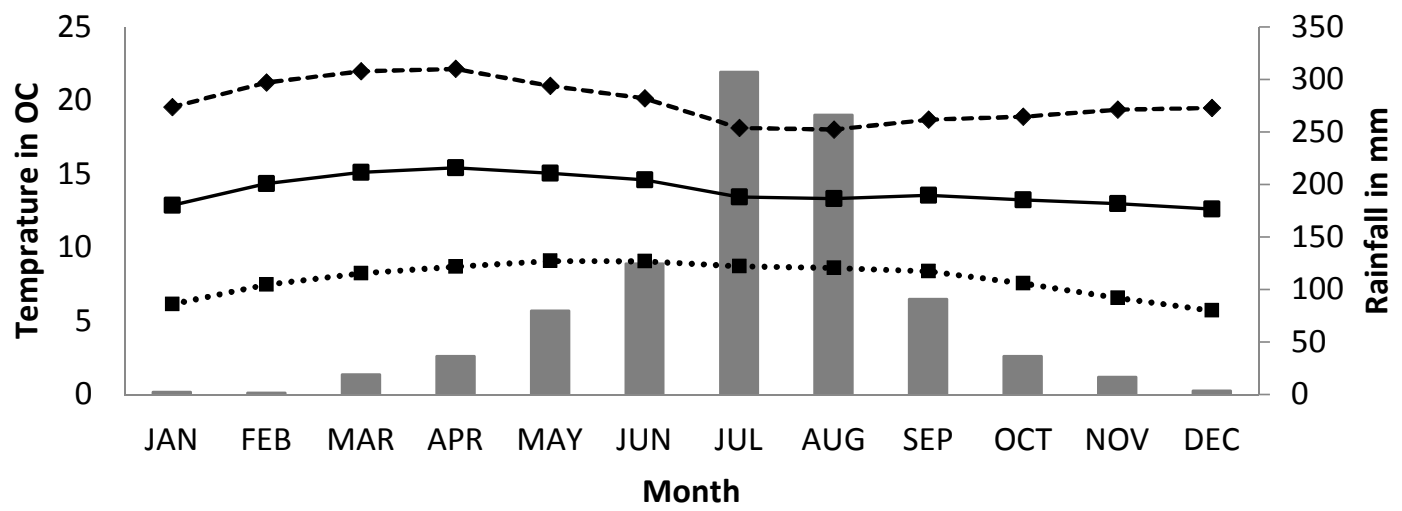

Rainfall $\longrightarrow$ - T average $\quad \cdots \cdot \cdots \cdot$ Tmin $\quad--\bullet-\cdot T \max$

Figure 3. Monthly total rainfall and average temperature for the study area (2004-2016)

\section{Sampling Design and Sample Size}

Multi stage Sampling was used because the population characteristics within the district is heterogonous in agroecology. In the first stage stratified random sampling was carried out by considering Kolla (lowland), Woyna Dega (midland) and Dega (highland). From total of 34 kebeles of the district Dega consists of 16 kebeles but, Woyna Dega and Kolla consist of nine kebeles each. In the second stage two kebeles were randomly selected from each agro-ecological zone (a total of six kebeles) and randomly selecting households from the six sampled kebeles using probability proportional to size (PPS). The sample size for household interview was calculated based on Cochran (1977) formula.

$$
n=\frac{z^{2} p q}{d^{2}}
$$

Where $\mathrm{n}=$ required sample size (when population is $>10,000), \mathrm{Z}=95 \%$ confident limit $(1.96), \mathrm{p}=$ proportion of population to be included in the sample which is $10 \%$ of the total population, $\mathrm{q}=1-\mathrm{P}=1-0.1=0.9, \mathrm{~N}=$ total number of population and $\mathrm{d}=$ margin of error $(5 \%)$. Then $n=(1.96)^{2 *} 0.1 * 0.9 /(0.05)^{2}=138$. Therefore, the sample size for this study was 138. After determining the sample size, the next step was determining the number of households for each sampled kebeles using probability proportional to size method. So, a total of 138 households (Dega $=46$, Woyna Dega $=46$ and Kolla $=46)$ were selected. The primary data for this study was collected using standard questionnaires prepared for the survey in July 2017. Secondary data were obtained from Bahir Dar meteorological service agency proxy stations of Chennek or Siemen Mountains $\left(13.27^{\circ} \mathrm{N}\right.$ and $\left.38.18^{\circ} \mathrm{E}\right)$ Debark $\left(13.16^{\circ} \mathrm{N}\right.$ and $\left.37.89^{\circ} \mathrm{E}\right)$, Guhala $\left(12.77^{\circ} \mathrm{N}\right.$ and $\left.38.8^{\circ} \mathrm{E}\right)$ and Amba-Giorgis $\left(12.77^{\circ} \mathrm{N}\right.$ and $\left.37.62^{\circ}\right)$. To verify the quantitative data, qualitative data were collected through focused group discussion (FGD) and key informants' interview.

\section{Method of Data Analysis}

The statistical data were entered and analyzed using SPSS version 23 and Spreadsheet 2016. Mann-Kendall statistical method was applied to annual distribution of rainfall and temperature to detect any possible trends in the data over the study period. This is a non-parametric statistical test well suited to measure trend in data over time (Karpouzos et al., 2010). Positive (+) values indicate an increase over time while, negative (-) values indicate decrease. The test observes whether a random response variable monotonically increases or decreases with time. All trend significant test with the level of significance $0.05\left(Z_{-} \alpha / 2= \pm 1.96\right)$. The hypothesis were null hypothesis (there is no significant trend) and alternative hypothesis (there is a significant trend). Mann-Kendall trend test was analyzed through XLSTAT 2016. Farmers' livelihood vulnerability to climate change and variability was analyzed at two sets of analysis. Calculation of a balanced weighted average LVI (referred to as model 1) and calculation of LVI based on the IPCC framework (IPCC, 2007b) (referred to as model 2). One-way ANOVA was used to revealed the significant difference in actual sub-components (vulnerability indicators) among the three agroecological zones.

\section{Livelihood Vulnerability Index (LVI) Analysis: Composite Index Approach}

The LVI developed by Hahn et al. (2009) was used to assess the rural households vulnerability to climate change and variability in Janamora district. In this approach, several sub-component combine into eight major components. Each of the eight major components is viewed as having an equal contribution (i.e. balanced weight) 
to a community's overall vulnerability (Sullivan et al., 2002). The computation of each indicator value followed the process of standardisation adopted from the computation of the life expectancy index of the HDI (Hahn et al. 2009). This computation is shown in Equation 1:

Index $S_{a}=\frac{s_{a-} s_{\min }}{S_{\max }-S_{\min }}$

In the index, $\mathrm{S}_{a}$ is the original (averaged) subcomponent for agro-ecology $a$ and $\mathrm{S}_{\min }$ and $\mathrm{S}_{\max }$ are the minimum and maximum values for each subcomponent determined using data from the three agro-ecological zones of the district. The percent of households reporting in their community was set at a minimum of 0 and a maximum of 100. After each was standardised, the subcomponent was averaged using Equation 2 to calculate the value of each major component:

$M_{a}=\frac{\sum_{i}^{n} \text { index } S_{a i}}{n}$

where $\mathrm{M}_{a}$ equals one of the major components for the agro-ecological zone $a$ (SDP,LS SN,N\&PA, H, F, W, $\mathrm{NDCV}$ ), indexs ${ }_{a}{ }^{\mathrm{i}}$ represents the subcomponents, indexed by $i$, that makes up each major component, and $n$ is the number of subcomponents in each major component. Once values for each of the eight major components for the agro-ecology was calculated, it was averaged using Equation 3 or 4 to obtain the LVI at agro-ecological zone level of the district:

$L V I_{a}=\frac{\sum_{i=1}^{n} W_{M i} M a}{\sum_{i=1}^{n} W_{M i}}$

(Equation 3)

which can also be shown as:

$L V I_{a}=\frac{W_{S D P} S D P_{a}+W_{L S} L S_{a}+W_{S N} S N_{a}+W_{N P A} N P A_{a}+W_{H} H_{a}+W_{F} F_{a}+W_{W} W_{d}+W_{N D C V} N D C V_{a}}{W_{S D P}+W_{L S}+W_{S N}+W_{N P A} W_{H}+W_{F}+W_{W}+W_{N D C V}}$ (Equation 4)

where $\mathrm{LVI}_{a}$ is the livelihood vulnerability index for the the agro-ecology within the district and the weightage of the eight major components, $W_{\mathrm{Mi}}$, determined by the number of subcomponents that make up each major component, contribute equally to the overall LVI (Hahn et al. 2009; Sullivan 2002). The LVI was scaled from 0 (least vulnerable) to 1 (most vulnerable).

\section{Calculating the LVI-IPCC framework approach}

LVI-IPCC was developed by IPCC by considering the three contributing factors (exposure, sensitivity and adaptive capacity) of vulnerability. The final composite LVI-IPCC score for each contributing factor was calculated with the formula (Hahn et al., 2009).

$C F a=\frac{\sum_{i=1}^{n} W_{M i *} M_{a i}}{\sum_{i=1}^{n} W_{M i}} \quad$ (equation 5)

where $\mathrm{CF}_{a}$ represents one of the IPCC-defined contributing factors to vulnerability for the agro-ecology $a . \mathrm{M}_{\mathrm{di}}$ represented the major components for the agro-ecology $a$ indexed by $\mathrm{i}, \mathrm{W}_{\mathrm{Mi}}$ is the weight of each major component, and $\mathrm{n}$ is the number of major components that made up each contributing factor. After the score for each contributing factor was calculated, they combined using this equation.

$L V I-I P C C_{a}=(E a-A a) * S a \quad$ (equation 6)

in which LVI-IPCC $a$ is the LVI for agro-ecology as within the IPCC framework, $E$ represented the score for exposure, $A$ is the score for adaptive capacity, and $S$ is the score for sensitivity. The scale for the LVI-IPCC is from -1.0 to 1.0 (Hahn et al., 2009).

\section{Results and Discussion}

The female headed household accounts $19.6 \%$ in Dega, 19.6\% in Woyna Dega and 15.2\% in Kolla agroecological zones. The mean age of the respondents were 47.4 years (Dega), 42 years (Woyna Dega) and 42.7 years (Kolla). The mean household size of the respondent was 6.065 (Dega), 5.826 (Woyna Dega) and 5.804 (Kolla). Which was greater than the national average household size (5.1 in rural and 3.9 in small town) of Ethiopia (CSA and World Bank, 2013). About 78.3\%, 76.1\% and 71.7\% sampled household heads in Dega, Woyna Dega and Kolla agroecologies were illiterate. Similarly, mean landholding size was 0.716 ha for Dega, 0.456 ha for Woyna Dega, and 0.888 ha for Kolla. Which was below the national average household farm size of 1.37 hectare (CSA and World Bank, 2013). The result was statistically significant $(\mathrm{F}=7.27, \mathrm{P}=0.001)$. The difference in land size between agroecological zones were as result of population density (dense in Dega and Woyna Dega but, sparse in Kolla).

\section{Observed and perceived Climate change and Variability Temperature change and Variability}

The Mann-Kendall trend test for annual minimum temperature revealed statistically significant increasing trend for Chennek and Guhala stations Similar to Birhanu Getachew (2017). However, annual minimum temperature showed an increasing trend in all stations (Table 1). Moreover, annual maximum temperature showed statistically significant increasing trend for Amba-Giorgis and Guhala stations (Table 1). Annual maximum temperature showed an increasing trend in all stations. Similarly, Chennek $(\mathrm{P}=0.000)$ Amba-Giorgis $(\mathrm{P}=0.010)$ and Guhala 
$(\mathrm{P}=0.000)$ stations showed statistically significant increasing trend for annual average temperature (Table 1$)$. Table 1. Annual temperature variability and Mann-Kendall trend Test

\begin{tabular}{lllllllllll}
\hline Station & Temperature & $\mathrm{N}$ & Min. & Max & Mean & SD & CV & $\begin{array}{l}\text { Trend } \\
\text { 'C/year }\end{array}$ & $\begin{array}{l}\text { Kendall's } \\
\text { tau }\end{array}$ & $\begin{array}{l}\text { P- } \\
\text { value }\end{array}$ \\
\hline Chennek & Tmin. & 13 & 2.80 & 7.74 & 4.231 & 1.396 & 0.33 & 0.0024 & 0.788 & $0.000^{*}$ \\
& Tmax. & 13 & 12.1 & 15.7 & 14.04 & 0.993 & 0.071 & 0.0014 & 0.272 & 0.121 \\
& T ave. & 13 & 7.41 & 11.5 & 9.13 & 1.015 & 0.111 & 0.0018 & 0.727 & $0.000^{*}$ \\
Debark & Tmin. & 13 & 7.80 & 9.27 & 8.588 & 0.393 & 0.046 & 0.0026 & 0.303 & 0.096 \\
& Tmax. & 13 & 18.2 & 21.1 & 19.78 & 0.802 & 0.041 & 0.0028 & 0.212 & 0.186 \\
\multirow{5}{*}{ Amba- Giorgis } & T ave. & 13 & 12.9 & 15.2 & 14.18 & 0.559 & 0.039 & 0.0027 & 0.182 & 0.225 \\
& Tmin. & 15 & 6.23 & 9.75 & 8.32 & 0.851 & 0.102 & 0.0033 & 0.154 & 0.251 \\
& Tmax. & 15 & 18.6 & 22.4 & 20.1 & 1.13 & 0.056 & 0.0141 & 0.670 & $0.000^{*}$ \\
Guhala & T ave. & 15 & 12.4 & 15.7 & 14.21 & 0.883 & 0.062 & 0.0087 & 0.473 & $0.010^{*}$ \\
& Tmin. & 30 & 4.39 & 15.9 & 10.38 & 3.027 & 0.292 & 0.0095 & 0.609 & $0.000^{*}$ \\
& Tmax. & 30 & 22.9 & 31.6 & 25.7 & 2.475 & 0.096 & 0.0075 & 0.513 & $0.000^{*}$ \\
& T ave. & 30 & 14.2 & 23.4 & 18.11 & 2.611 & 0.144 & 0.0085 & 0.655 & $0.000^{*}$ \\
\hline
\end{tabular}

*is significant trend at $\mathrm{P}<0.05$ level, $\mathrm{SD}=$ Standard Deviation, $\mathrm{CV}=$ Coefficient of Variance (Source: Bahir Dar meteorological agency, 2017).

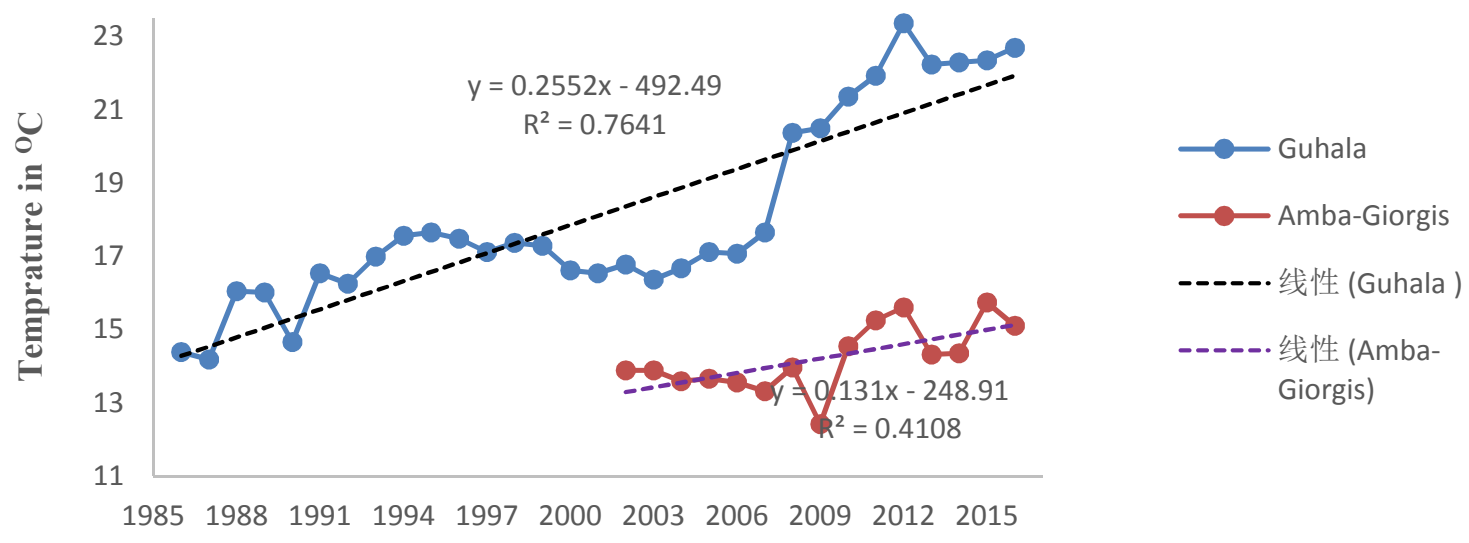

However, annual average temperature of Debark station was statistically insignificant but an increasing trend. Moreover, Figure 4 showed that both Amba-Giorgis and Guhala stations showed a positive slope that revealed an increasing trend of average temperature. Generally, statistically significant increasing trend was observed on annual average temperature for Chennek, Amba-Giorgis and Guhala stations. This is in accordance with the current national temperature increment (increased by $0.03^{\circ} \mathrm{C}$ per year) of Ethiopia (Jury and Funk, 2012).

\section{Perceived Temperature change and Variability}

Most of the respondents from each agro-ecologies (73.78\% from Dega, 56.42\% from Woyna Dega and 78.12\% from Kolla) perceived that temperature is increased (Table 2). The change in temperature occurred in all agroecologies and it was felt more or less equal by every farming community in the district. There was a significant difference in perception of male and female to temperature change $\left(\chi^{2}=20.15\right)$ (Table 2$)$. This difference in perception between gender is a reflection of the roles that the two sexes play in the society and the limited opportunities available to woman in terms of climate related information. Marther et al. (2016) and Alem Kidanu et al (2016) found significant difference perception between male and female. 
Table 2: Perceived temperature change and variability

\begin{tabular}{|c|c|c|c|c|c|c|}
\hline \multirow[b]{2}{*}{ Agro-ecology } & \multicolumn{4}{|c|}{ Perception on temperature (\% of respondents) } & \multirow[t]{2}{*}{$\chi^{2}$} & \multirow[t]{2}{*}{ P-value } \\
\hline & I don't know & Decreased & Increased & No Change & & \\
\hline Dega & 2.17 & 19.53 & 73.78 & 4.34 & & \\
\hline Woyna Dega & 10.85 & 28.21 & 56.42 & 4.34 & $10.21^{\mathrm{ns}}$ & 0.116 \\
\hline Kolla & 10.85 & 10.85 & 78.12 & 0 & & \\
\hline \multirow[t]{2}{*}{ Gender } & \multicolumn{4}{|c|}{ Perception on temperature ( $\%$ of respondents) } & & \\
\hline & I don't know & Decreased & Increased & No Change & & \\
\hline male & 5.07 & 17.4 & 59.4 & 1.5 & $20.15^{*}$ & 0.000 \\
\hline female & 5.07 & 5.07 & 5.07 & 1.5 & & \\
\hline \multirow{2}{*}{$\begin{array}{l}\text { Educational } \\
\text { Status } \\
\end{array}$} & \multicolumn{4}{|c|}{ Perception on temperature (\% of Respondents) } & & \\
\hline & I don't know & Decreased & Increased & No Change & & \\
\hline Illiterate & 12 & 22.2 & 63 & 2.8 & $9.93 *$ & 0.019 \\
\hline Literate & 0 & 6.9 & 93.1 & 0 & & \\
\hline
\end{tabular}

${ }^{\mathrm{ns}}$ and* is non-significant and significant at 0.05 level respectively

Chi-square shows significant variation among the different educational status $\left(\chi^{2}=9.93, \mathrm{P}=0.019\right)$ (Table 2). The implication is that educated peoples are keener in noting changes in temperature more than uneducated people; they become very conscious about their environment.

\section{Rainfall Change and Variability}

All the months in Amba-Giorgis station varied from $33.2 \%$ - 318.6\% CV showing very high variability of precipitation (Hare, 2003). The annual variability of rainfall as indicated in Table 4, is moderately variable for Amba-Giorgis $(\mathrm{CV}=28.33 \%)$ and Chennek $(\mathrm{CV}=20.77 \%)$ stations. Whereas, Debark and Guhala stations were less variable.

Table 3. Annual rainfall variability and Man-Kendall trend analysis

\begin{tabular}{lccccccccc}
\hline Stations & N & Min. & Max. & Mean & SD & CV & $\begin{array}{l}\text { Trend } \\
\text { mm/year }\end{array}$ & $\begin{array}{l}\text { Kendall's } \\
\text { tau }\end{array}$ & p-value \\
\hline Chennek & 13 & 666.6 & 1610.4 & 1071.7 & 222.6 & 0.21 & 0.392 & 0.061 & $0.418 \mathrm{~ns}$ \\
Debark & 13 & 811.9 & 1615.1 & 1127.8 & 208.2 & 0.19 & -0.086 & -0.12 & $0.684 \mathrm{~ns}$ \\
Amba- Giorgis & 28 & 527.3 & 1701.7 & 1002.3 & 283. & 0.28 & 0.462 & 0.154 & $0.251 \mathrm{~ns}$ \\
Guhala & 13 & 569.3 & 939 & 733.7 & 110 & 0.15 & -0.919 & 0.048 & $0.369 \mathrm{~ns}$ \\
\hline
\end{tabular}

ns is non-significant trend at 5\% level, $\mathrm{SD}=$ Standard Deviation, $\mathrm{CV}=$ Coefficient of Variance and $\mathrm{MK}=\mathrm{Mann}-$ Kendall

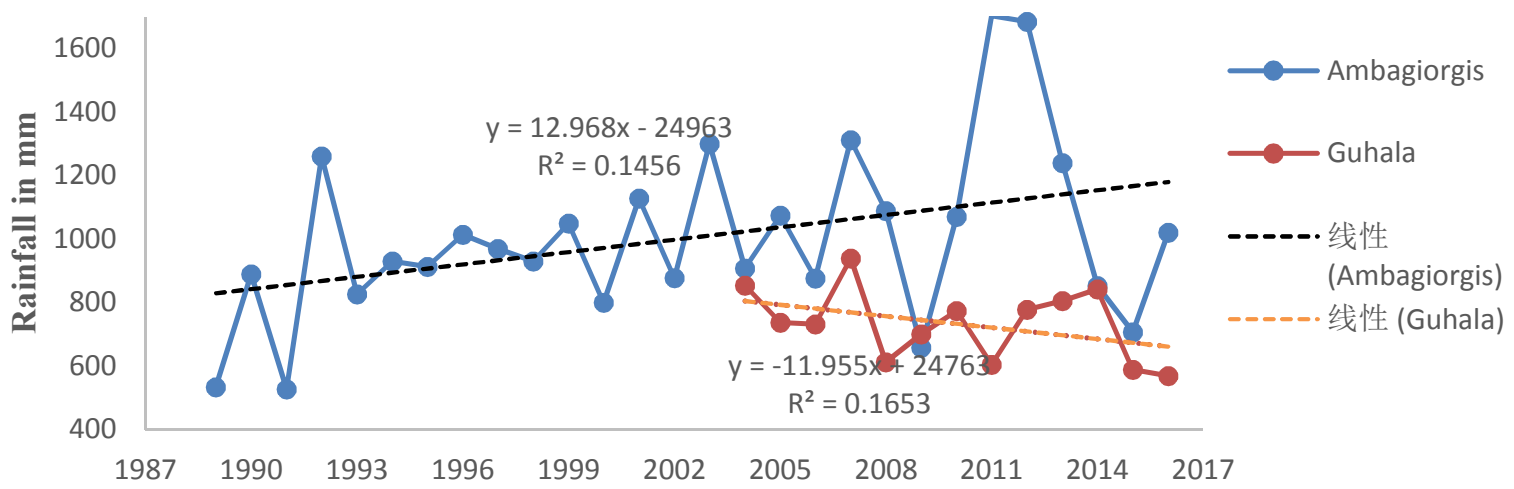

Figure 5: Trends of annual rainfall for Amba-Giorgis and Guhala stations respectively. (Source: Bahir Dar meteorological agency, 2017).

The Mann-Kendall trend test for annual rainfall revealed statistically insignificant trend for all stations. However, a decreasing trend was seen in Debark and Guhala stations (Table 3). Similarly, Birhan Getachew (2017) found insignificant trend in annual rainfall. Figure 5 showed that Amba-Giorgis have a positive slope with increasing rainfall and Guhala has a negative slope that revealed decreasing rainfall. In general, very high variability and insignificant trend of rainfall was observed. This implies that agricultural activities in the district are challenged by such high variabilities and a decreasing trend of rainfall. Most of the respondents (80.4\%) believed a decrease in the amount of rainfall, and the remaining and $28.7 \%$ of the respondents did not give enough attention about the trend of the rainfall. Similarly, through Focus group discussion (FGD), farmers of the district generally concurred that the main problem in terms of rainfall distribution is the timing (late onset and early 
cessation) and falling in intense episodes in very short duration. statistical analysis showed significant variation of perception across different agro-ecological zones $\left(\chi^{2}=22.19\right)$ (Table 5). Similar to ATPS (2013) study. This is probably because in Kolla agro-ecology, water is already very scarce, and a little change in the amount of rainfall could have high impact.

Table 4. Farmers' perception on rainfall change and variability

\begin{tabular}{|c|c|c|c|c|c|c|}
\hline \multirow[b]{2}{*}{ Agro-ecology } & \multicolumn{4}{|c|}{ Perception on temperature (\% of respondents) } & \multirow[t]{2}{*}{$\chi^{2}$} & \multirow[t]{2}{*}{ P-value } \\
\hline & I don’t know & Decreased & Increased & No Change & & \\
\hline Dega & 8.68 & 32.55 & 54.25 & 4.34 & & \\
\hline Woyna Dega & 10.85 & 6.51 & 78.12 & 4.34 & $22.19 *$ & 0.001 \\
\hline Kolla & 6.51 & 2.17 & 86.8 & 4.34 & & \\
\hline \multirow[t]{2}{*}{ Gender } & \multicolumn{4}{|c|}{ Perception on temperature (\% of respondents) } & & \\
\hline & I don’t know & Decreased & Increased & No Change & & \\
\hline male & 3.6 & 5.8 & 71.02 & 2.9 & $18.36^{*}$ & 0.000 \\
\hline female & 5.07 & 0.73 & 9.42 & 1.5 & & \\
\hline \multirow{2}{*}{$\begin{array}{l}\text { Educational } \\
\text { Status }\end{array}$} & \multicolumn{4}{|c|}{ Perception on temperature (\% of Respondents) } & & \\
\hline & I don't know & Decreased & Increased & No Change & & \\
\hline Illiterate & 9.2 & 21.1 & 66.1 & 3.7 & $13.45^{*}$ & 0.004 \\
\hline Literate & 0 & 3.5 & 95.5 & 0 & & \\
\hline
\end{tabular}

ns and* is non-significant and significant at 0.05 level respectively

There was statistically significant variation of perception in rainfall by gender $\left(\chi^{2}=18.36\right)$ (Table 4$)$ Marther W. et al. (2016), ATPS (2013) and Alem Kidanu et al (2016) also revealed that significant difference perception between male and female to climate change. Moreover, the statistical analysis for perception of rainfall change showed significant variation among the different educational status $\left(\chi^{2}=13.45\right)$ (Table 4$)$. About $60.9 \%, 78.3 \%$ and $84.8 \%$ of respondents from Dega, Woyna Dega and Kolla agro-ecologies were well recognized the existence of drought in their local area respectively.

\section{Farmers' Vulnerability to Climate Change and Variability} Livelihood vulnerability index results

The unit of analysis for the livelihood vulnerability of farmers was Dega (Highland), Woyna Dega (Midland) and Kolla (Lowland) agro-ecological zones (AEZs). The indexed sub-components, the major components, and the composite LVI for each agro-ecologies are represented in Table 6. Empirically, the vulnerability indices of the major components ranged from $0.314-0.577$ as shown in Table 6 .

The first major component is the socio-demographic profile which consists of five sub components. In case of socio-demographic profile, Dega (0.404) was found to be the most vulnerable followed by Kolla (0.377). But Woyna Dega was relatively the least vulnerable (0.352) Similarly, ANOVA test $(\mathrm{p}=0.02)$ revealed a significant variation in dependency ratio among AEZs. On the other hand, Dega (19.6\%) and Woyna Dega (19.6\%) have a higher proportion of female-headed households than Kolla (15.2\%). Majority of the household heads in Dega $(78.3 \%)$ reported not having any formal education followed by Woyna Dega $(76.1 \%)$. Illiteracy limits farmer's access to information especially from written sources, by increasing their susceptibility to climatic stresses (Etwire P.M. et al. 2013).

Livelihood strategy is the second major component which is made from three sub components. In livelihood strategy Dega (0.459) was the most vulnerable but Woyna Dega (0.418) was the least vulnerable. This was due to shortage of land, inadequate livelihoods option, and population pressure (similar to the findings of Chala Dechassa et al (2016)). In addition. $82.6 \%, 80.5 \%$ and $87 \%$ of the respondents dependent solely on agriculture in Dega, Woyna Dega and Kolla AEZs respectively. One-way ANOVA result $(\mathrm{p}=0.041)$ revealed statistically significant variation in agricultural livelihood diversification index between AEZs.

The third major component is social networks which is also made up of three sub components. Even though the indices for the three AEZs were similar, Kolla (0.342) was found to be the most vulnerable in terms of social networking relative to Woyna Dega (0.321) and Dega (0.314) (Table 6). Average receive to give ratio of Kolla (0.443) was the largest ratio relative to Dega (0.319) and Woyna Dega (0.254).

Natural and physical asset is the fourth major component with two sub-components. In regard to natural and physical asset, Woyna Dega with index of 0.368 was the most vulnerable to climate variabilities and changes. Whereas Dega and Kolla agro-ecological zones are all most similar in vulnerability with index of 0.357 and 0.354 respectively. In addition, one-way ANOVA $(\mathrm{p}=0.004)$ showed a significant different average land size index among AEZs. When population density increased, the land size given to each household becomes reduced.

Health is the fifth major component. When the three sub components are aggregated to form an index, Kolla with an index of 0.52 was the most vulnerable to health whereas, Dega $(0.429)$ was the least vulnerable. The reason behind was malaria and other water born disease are dominant in Kolla (lowland) agro-ecology. The average time 
taken to reach a health facility was highest for Kolla (278.48 minute). Similarly, one-way ANOVA result ( $\mathrm{p}=$ 0.016) revealed significant variation in time taken to reach a health facility between AEZs. This illustrates shortage of health service access resulting from lack of road and other infrastructures mostly in Kolla agro-ecological zone. There is significant $(\mathrm{p}=0.002)$ difference percent of households with chronic illness between AEZs. Sickness increases the vulnerability of farmers to other external stresses. The overall index for health was the highest in Kolla and the lowest in Dega AEZs. Since the exposure of environment to disease in Kolla the increased availability of health facilities tends to reduce the overall index for health (Sattar et al., 2017).

Food is the sixth major component made up of five sub components. The Households in Kolla was the most vulnerable to food inaccessibility with an index of 0.577 but, Dega $(0.433)$ was relatively the least vulnerable. Almost all percentages of households in Dega (97.8\%) and Kolla (97.8\%) rely solely on their farm for food. The average number of months households struggle to find food was found to be highest in Kolla (6.11 months) and Woyna Dega (5.15 months) relative to Dega (4.15 months) and it was statistically significant $(\mathrm{p}=0.000)$ between AEZs. The actual Average crop diversity index shows households grow 3.32 types of crops in Dega, 3.89 types of crops in Woyna Dega and 3.48 types of crops in Kolla. Similarly, crop diversity index was statistically significant $(\mathrm{p}=0.000)$ among AEZs. So, farmers of Woyna Dega and Kolla grows relatively more types of crops than farmers of Dega. This is because climatic condition in Dega agro-ecology restrict the type of crops that grow. The smaller land size also affects the type of crops a farmer can grow.

The vulnerability index for the seventh major component (water) shows Woyna Dega (0.644) to be the most vulnerable but Dega (0.459) was the least vulnerable. Woyna Dega (82.6\%) and Kolla (80.4\%) recorded the highest percentage of households reporting conflicts over water resources in the past years. Households of Kolla and Woyna Dega travel an average of 129.89 and 141.3 minute to get water source respectively. Whereas farmers of Dega travel only an average of 76.739 minute to the water source as well as One-way ANOVA showed significant $(\mathrm{p}=0.000)$ between AEZs Therefore, the average time taken to reach the water source is found to be highest (similar to the study of Chala Dechassa et al (2016)) in Kolla. This shows less accessibility of different water sources like bore holes and modern drinking water sources mostly in Kolla and Woyna Dega AEZs.

The eighth major component is the natural disasters and climate variability (NDCV) component which was comprised of six sub components. Respondents in Kolla with index of 0.471 were found to be the most vulnerable followed by Dega (0.467) but, households of Woyna Dega (0.437) was relatively the least vulnerable. In households of Woyna Dega highest average number of climate hazards (10.96 climatic hazards per decade) were occurred but in Dega the hazards were relatively lowest (7.935 climatic hazards per decade). Moreover, one-way ANOVA showed significant different number of hazards among AEZs. Majority of farmers (97.8\%) in all three agro-ecological zones did not receive any warning about impending natural disaster such as floods or droughts. In addition, agricultural office report of the district realized that less ground water reserves, low vegetation cover, soil erosion and increased flooding and rainfall variability and shortage are some of the worst environmental externalities of the district.

The overall livelihood vulnerability index (LVI) score was the highest for Kolla (0.471) followed by Woyna Dega (0.454) AEZ. Whereas, it was the lowest for Dega (0.425) agro-ecology. This implies that farmers of Kolla was the most vulnerable (similar to the finding of Chala Dechassa et al. (2016)). On the contrary farmers of Dega was relatively the least vulnerable to climate change and variabilities.

Livelihood vulnerability index IPCC approach results

Table 5. LVI-IPCC contributing factors calculation for the study area

\begin{tabular}{|c|c|c|c|c|c|}
\hline \multirow[t]{2}{*}{ Major Component } & \multirow[t]{2}{*}{ № of Sub-components } & \multirow[t]{2}{*}{ Contributing factors } & \multicolumn{3}{|c|}{ Contributing factors value } \\
\hline & & & Dega & Woyna Dega & Kolla \\
\hline SDP & 5 & \multirow[t]{4}{*}{ Adaptive Capacity } & \multirow[t]{4}{*}{0.388} & \multirow[t]{4}{*}{0.363} & \multirow[t]{4}{*}{0.382} \\
\hline LS & 3 & & & & \\
\hline $\mathrm{SN}$ & 3 & & & & \\
\hline N \&PA & 2 & & & & \\
\hline Health & 3 & \multirow[t]{3}{*}{ Sensitivity } & \multirow[t]{3}{*}{0.442} & \multirow[t]{3}{*}{0.554} & \multirow[t]{3}{*}{0.557} \\
\hline Food & 5 & & & & \\
\hline Water & 5 & & & & \\
\hline \multirow[t]{2}{*}{ NDCV } & 6 & Exposure & 0.467 & 0.437 & 0.471 \\
\hline & & LVI-IPCC & 0.035 & 0.041 & 0.049 \\
\hline
\end{tabular}

households of Kolla with exposure score of 0.471 was the most exposed and farmers of Woyna Dega (0.437) was relatively the least exposed. Similarly, Kolla $(0.557)$ might be the most sensitive to climate change impacts but, Dega (0.442) was the least sensitive. By adaptive capacity, Dega that showed the highest score (0.388) have the lowest adaptive capacity. However, Woyna Dega (0.363) that showed the lowest score (0.388) have the highest adaptive capacity. Generally, LVI-IPCC analysis results were $0.035,0.041$ and 0.049 for Dega, Woyna Dega and 
Kolla AEZs respectively. Therefore, households of Kolla were the most vulnerable followed by that of Woyna Dega. whereas, farmers in Dega (LVI-IPCC $=0.035)$ were the least vulnerable to climate change and variability risks.

Table 6: Indexed sub-components, major components and overall LVI for the three agro-ecologies of Janamora district

\begin{tabular}{|c|c|c|c|c|c|c|c|}
\hline Sub-components/Vulnerability Indicators & Dega & Woyna-Dega & Kolla & $\begin{array}{l}\text { Major } \\
\text { Component }\end{array}$ & Dega & Woyna Dega & Kolla \\
\hline $\begin{array}{l}\text { Dependency ratio } \\
\% \text { of female-headed household } \\
\text { Average age of female headed household (1/years) } \\
\% \text { of household heads haven't attended school } \\
\% \text { of households with orphans }\end{array}$ & \begin{tabular}{|l|}
0.440 \\
0.196 \\
0.472 \\
0.783 \\
0.13 \\
\end{tabular} & \begin{tabular}{l|l|}
0.339 \\
0.196 \\
0.336 \\
0.761 \\
0.13 \\
\end{tabular} & $\begin{array}{l}0.474 \\
0.152 \\
0.400 \\
0.717 \\
0.142\end{array}$ & SDP & 0.404 & 0.352 & 0.377 \\
\hline $\begin{array}{l}\% \text { of } \mathrm{HHs} \text { working in a different community } \\
\% \text { of } \mathrm{HHs} \text { dependent solely on agriculture } \\
\text { Average agricultural LDI }\end{array}$ & \begin{tabular}{|l|}
0.174 \\
0.826 \\
0.376 \\
\end{tabular} & \begin{tabular}{ll|}
0.217 \\
0.805 \\
0.233 \\
\end{tabular} & $\begin{array}{l}0.196 \\
0.87 \\
0.28 \\
\end{array}$ & LS & 0.459 & 0.418 & 0.449 \\
\hline $\begin{array}{l}\text { Average receive: give a ratio } \\
\text { Average borrows: lend money ratio } \\
\% \text { of HHs who has not gone to their local government for } \\
\text { assistance } / 12 \text { months }\end{array}$ & $\begin{array}{l}0.319 \\
0.319 \\
0.304\end{array}$ & $\begin{array}{l}0.254 \\
0.405 \\
0.304\end{array}$ & $\begin{array}{l}0.443 \\
0.367 \\
0.217\end{array}$ & SN & 0.314 & 0.321 & 0.342 \\
\hline $\begin{array}{l}\text { Inverse of average land size index } \\
\% \text { of landless farmers }\end{array}$ & \begin{tabular}{|l|}
0.761 \\
0.02 \\
\end{tabular} & $\begin{array}{ll}0.848 \\
0.04\end{array}$ & $\begin{array}{l}0.704 \\
0.01\end{array}$ & NPA & 0.357 & 0.368 & 0.354 \\
\hline $\begin{array}{l}\text { Average time to health facility } \\
\% \text { of HHs with chronic illness } \\
\% \text { of HHs where a family member had to } \\
\text { miss work in the past } 2 \text { weeks due to Illness }\end{array}$ & \begin{tabular}{|l|}
0.158 \\
0.696 \\
0.435
\end{tabular} & $\begin{array}{l}0.207 \\
0.609 \\
0.543\end{array}$ & $\begin{array}{l}0.365 \\
0.804 \\
0.391\end{array}$ & Health & 0.429 & 0.453 & 0.52 \\
\hline $\begin{array}{l}\% \text { of HHs dependent solely on farm for food } \\
\text { Average number of months, food shortage } \\
\text { Average crop diversity index } \\
\% \text { of HHs that does not save crops } \\
\% \text { of HHs that does not save seeds }\end{array}$ & \begin{tabular}{|l|}
0.978 \\
0.287 \\
0.205 \\
0.543 \\
0.152 \\
\end{tabular} & $\begin{array}{l}0.935 \\
0.377 \\
0.272 \\
0.717 \\
0.326 \\
\end{array}$ & $\begin{array}{l}0.978 \\
0.465 \\
0.223 \\
0.87 \\
0.348\end{array}$ & Food & 0.433 & 0.525 & 0.577 \\
\hline $\begin{array}{l}\% \text { of } \mathrm{HHs} \text { reported water conflicts } \\
\% \text { of } \mathrm{HH} \text { s that utilizes a natural water source } \\
\text { Average time to water source } \\
\% \text { of HHs that do not have a consistent water } \\
\text { Water stored per HH ( } 1 / \text { the average number of liters) }\end{array}$ & \begin{tabular}{|l|}
0.587 \\
0.848 \\
0.094 \\
0.5 \\
0.264 \\
\end{tabular} & $\begin{array}{l}0.826 \\
0.957 \\
0.185 \\
0.761 \\
0.490 \\
\end{array}$ & $\begin{array}{l}0.804 \\
0.978 \\
0.169 \\
0.478 \\
0.363\end{array}$ & Water & 0.459 & 0.644 & 0.558 \\
\hline $\begin{array}{l}\text { Average number of climate hazards/decade } \\
\% \text { of HHs that did not get a warning }\end{array}$ & $\begin{array}{l}0.424 \\
0.978\end{array}$ & $\begin{array}{l}0.64 \\
0.978\end{array}$ & $\begin{array}{l}0.511 \\
0.978\end{array}$ & NDCV & 0.467 & 0.437 & 0.471 \\
\hline $\begin{array}{l}\text { \%of HHs with an injury/death } \\
\text { Mean SD of monthly Tmax. (2004-2016) } \\
\text { Mean SD of monthly Tmin. (2004-2016) } \\
\text { Mean SD of monthly RF (2004-2016) }\end{array}$ & $\begin{array}{l}0.261 \\
0.268 \\
0.434 \\
0.439\end{array}$ & $\begin{array}{l}0.239 \\
0.322 \\
0.228 \\
0.214\end{array}$ & $\begin{array}{l}0.196 \\
0.269 \\
0.367 \\
0.505\end{array}$ & & & & \\
\hline Over all LVI & & & & & 0.425 & 0.454 & 0.471 \\
\hline
\end{tabular}

\section{Conclusion and Recommendations}

Generally, significant increasing trend was observed on annual average temperature for all stations except Debark. However, insignificant trend was observed on rainfall of all stations. but Debark and Guhala stations showed a decreasing trend. Similarly, farmers perception was in line with the observed climatic data. Both LVI and LVIIPCC methods provide a detailed description of factors driving farmers' livelihood vulnerability to climate change and variability. Lack of climate information, fluctuations in precipitation, solely agricultural dependency and inadequate access to food and medicine and chronic illness were the constraining factor in increasing the vulnerabilities of farming communities in Kolla agro-ecology. Whereas, Woyna Dega agro-ecology is most vulnerable to water and natural and physical asset, while Dega is most vulnerable in terms of illiteracy, sociodemographic profile and livelihood strategies.

Stakeholders should to improve health, food and water supply in Woyna Dega and Kolla agro-ecological zones by undertaking different measures. Integrating rural development schemes aimed to increase adaptive capacity of farmers is recommended to the range of climate extremes that they experience. For the future, similar studies should be conducted by including governance indicators and other environmental factors with refinement of the social networks sub-components

\section{Reference}

Alem Kidanu, Kibebew Kibret, Jemma Hajji, Muktar Mohammed and Yosef Ameha. 2016. Farmers' perception towards climate change and their adaptation measures in Dire Dawa Administration, Eastern Ethiopia. Journal of Agricultural Extension and Rural Development. Vol.8(12), pp. 269-283.

ATPS (African Technology Policy Studies Network). 2013. Farmers' Perception and Adaptive Capacity to Climate Change and Variability in the Upper Catchment of Blue Nile, Ethiopia (Bewket Amdu, Azemeraw Ayehu, Andent Deressa), ATPS Working paper No. 77.

Belay Simane, Zaitchik J. D., and Foltz J.D. 2014. Agroecosystem specific climate vulnerability analysis: application of the livelihood vulnerability index to a tropical highland region. Mitig Adapt Strateg Glob Change 21 pp 39-65.

Birhan Getachew. 2017. Trend analysis of temperature and rainfall in south Gonder zone, Ethiopia. Journal of Degraded and Mining Lands Management. ISSN 5 pp 1111-1125. 
Bryan E., Ringler C., Okoba B., Roncoli C., Silvestri S. and Herrero M. 2010. Coping with climate variability and Adapting to Climate Change in Kenya: Household and community Strategies and Determinants. Kenya Agricultural Research Institute (KARI), Washington, Nairobi, Kenya.

Can N. D., Tu V. H., and Hoanh C. T. 2013. Application of livelihood vulnerability index to assess risks from flood vulnerability and climate variability-A case study in the Mekong Delta of Vietnam. Journal of Environmental Science and Engineering, 2 (8A), 476-486.

Chala Dechassa, Belay Simane, Bamlaku Alamirew and Hossien Azadi. 2016. agro-ecological based small-holder farmer's livelihoods vulnerability to climate variability and change in Didesa sub Basin of Blue Nile River, Ethiopia. Academia Journal of Agricultural Research; Dechassa et al. V. 4(5) pp $230-240$.

Challinor A, Wheeler T, Garforth C, Craufurd P, Kassam, A. 2007. Assessing the vulnerability of food crop systems in Africa to climate change. Climatic Change, 83 (3). 381 - 399. ISSN 0165-0009

Cochran, W. G. 1977. Sampling techniques (3rd ed.). New York: John Wiley \& Sons.

Conway, D. and Schipper, F. 2011. Adaptation to climate change in Africa: challenges and opportunities identified from Ethiopia. Global Environmental Change, 21(1), pp.227-237.

CSA (Central Statistical Agency) and the World Bank. 2013. Ethiopia Rural Socio-economic Survey (ERSS). Survey Report.

Edame GE., Ekpenyong AB. and Fonta WM. 2011. Climate Change, food security and agricultural productivity in Africa: Issues and policy directions. International Journal of Humanities and Social Science. Vol. 1 No. 21 pp 205- 223.

Etwire P. M., Al-Hassan R. M., Kuwornu J. K. and Osei-Owus Y. 2013. Application of livelihood vulnerability index in assessing vulnerability to climate change and variability in Northern Ghana. Journal of Environment and Earth Science, 3(2), 157-170

Hahn MB., Riederer AM. and Foster SO. 2009. The Livelihood Vulnerability Index: A pragmatic approach to assessing risks from climate variability and change a case study in Mozambique. Global Environmental Change 19: 74-88.

Hare W. 2003. Assessment of Knowledge on Impacts of Climate Change Contribution to the Specification of Art. 2 of the UNFCCC.

ILRI (International Livestock Research Institute). 2006. Mapping climate vulnerability and poverty in Africa. 200p Nairobi (Kenya): ILRI.

IPCC (Intergovernmental Panel on Climate Change). 2001. Climate change: The scientific basis. Contribution of Working Group I to the Third Assessment Report of IPCC (Houghton J.T., Ding Y., Griggs D.J., Noguer M., van der Linden P.J., Dai X., Maskell K., and. Johnson C.A).

IPCC (Intergovernmental Panel on Climate Change). 2007a. Climate change 2007: Impacts, adaptation, and vulnerability. Contribution of working group II to the third assessment report of the intergovernmental panel on climate change. (Parry M., Canziani O., Palutikof J., Van der Linden P. and Hanson C. Eds.) Cambridge, United Kingdom: Cambridge University Press.

IPCC (Intergovernmental Panel on Climate Change). 2007b. Fourth Assessment Report. Climate Change 2007 : Synthesis Report.

Jury M. R. and Funk C. 2012. Climatic trends over Ethiopia: regional signals and drivers. International Journal of Climatology. 33: 1924-1935 (2013).

Karpouzos D. K., Kavalieratou S. and Babajimopoulos C. 2010. Trend analysis of precipitation data in Pieria Region (Greece); European Water 30. 31- 40.

Kaur N, Million Getnet, Beneberu Shimelis, Zegeye Tesfaye, Gebeyehu Syoum and Endale Atnafu. 2010. Adapting to climate change in the water sector: Assessing the effectiveness of planned adaptation interventions in reducing local level vulnerability. Working Paper 18 Research-inspired Policy and Practice Learning in Ethiopia and the Nile Region. Debrezeit Road, PO Box 4812, Addis Ababa, Ethiopia

Koya M., Dash G., Kumari S., Sreenath K. R., Dash S. S., Ambrose T. V. and Zacharia P. U. 2017. Vulnerability of Coastal Fisher Households to Climate Change: A Case Study from Gujarat, India. Turkish Journal of Fisheries and Aquatic Sciences, 17, 193-203

Mahmud Yesuf, Salvatore D. F., Temesgen Deressa, Claudia R., and Gunnar K. 2008. The impact of climate change and adaptation on food production in low-income countries: Evidence from the Nile Basin, Ethiopia, IFPRI.

Marther W. Ngigi U. M. and Regina B. 2016. Gender differences in climate change perceptions and adaptation strategies: an intra-household analysis from rural Kenya, ZEF Discussion Papers on Development Policy No. 210, Center for Development Research, Bonn, March 2016, pp. 34.

MOA (Ministry of Agriculture). 2000. Agroecological Zonation of Ethiopia. Addis Ababa, Ethiopia.

MOARD (Minister of Agriculture and Rural Development). 2010. Ethiopia's Agricultural Sector Policy and Investment Framework. Addis Ababa, Ethiopia.

NMA (National Metrological Agency). 2001. Initial National Communication of Ethiopia to the united Nations 
Framework Convention on Climate Change (UNFCCC). NMA, Addis Ababa. Ethiopia.

Sattar R. S., Wang S., Tahir M. N. and Caldwell C. 2017. Assessment of Smallholder Farmer's Vulnerability Due to Climate Change in Arid Areas of Pakistan. Applied Ecology and Environmental Research. 15(4) 291-312.

Shah K. U., Dulal H. B., Johnson C., and Baptiste A. 2013. Understanding livelihood vulnerability to climate change: Applying the livelihood vulnerability index in Trinidad and Tobago. Geoforum, 47, 125-137

Solomon Addisu, Olutayo OA, Sulaiman H. and Rao P. 2016. Assessing Climate Change Impacts in the Lake Tana Sub-Basin, Ethiopia Using Livelihood Vulnerability Approach. Journal of Earth Science and Climate Change. 7: 9: 368-378.

Sullivan C., Meigh J.R., and Fediw T.S. 2002. Derivation and testing of the water poverty index phase 1, Final Report. Department for International Development, UK,2002.

Temesgen Deressa, Hassen R., Ringler C. 2008. Measuring Ethiopian farmer's vulnerability to climate change across regional states. International Food policy Research Institute IFPRI Discussion Paper 00806.

Temesgen Deressa. 2010. Assessment of the vulnerability of Ethiopian agriculture to climate change and farmers' adaptation strategies. $\mathrm{PhD}$ dissertation. University of Pretoria. SA

Theodrose Sisay. 2016. Vulnerability of Smallholder Farmers to Climate Change at Dabat and West Belesa Districts, North Gondar, Ethiopia. Journal of Earth Science and Climate Change. 7: 365. doi: 10.4172/21577617.1000365. 